Article

\title{
Light Intensity and Nitrogen Concentration Impact on the Biomass and Phycoerythrin Production by Porphyridium purpureum
}

\author{
Juan Eduardo Sosa-Hernández ${ }^{1}{ }^{\circledR}$, Laura Isabel Rodas-Zuluaga ${ }^{1}{ }^{\circledR}$, Carlos Castillo-Zacarías ${ }^{1}$, \\ Magdalena Rostro-Alanís ${ }^{1}$, Reynaldo de la Cruz ${ }^{1}$, Danay Carrillo-Nieves ${ }^{2}$ (D), \\ Carmen Salinas-Salazar ${ }^{1}{ }^{D}$, Claudio Fuentes Grunewald ${ }^{3}{ }^{(D}$, Carole A. Llewellyn ${ }^{3}{ }^{(D)}$, \\ Eugenia J. Olguín ${ }^{4}$, Robert W. Lovitt ${ }^{5,6}$, Hafiz M. N. Iqbal ${ }^{1, *(\mathbb{D})}$ and Roberto Parra-Saldívar ${ }^{1, *(\mathbb{D})}$ \\ 1 Tecnologico de Monterrey, Escuela de Ingenieria y Ciencias, Campus Monterrey, \\ Ave. Eugenio Garza Sada 2501, Monterrey, Nuevo Leon 64849, Mexico \\ 2 Tecnologico de Monterrey, Escuela de Ingenieria y Ciencias, Av. General Ramón Corona 2514, \\ Nuevo México, Zapopan C.P. 45138, Jalisco, Mexico \\ 3 Department of Biosciences, Singleton Park, Swansea University, Swansea, Wales SA2 8PP, UK \\ 4 Environmental Biotechnology Group, Institute of Ecology(INECOL), Carretera Antigua a Coatepec No. 351, \\ Xalapa, Veracruz 91070, Mexico \\ 5 College of Engineering, Swansea University, Swansea SA2 8PP, UK \\ 6 Membranology Ltd., Unit D5 Rainbow Business Centre, Swansea SA7 9FP, UK \\ * Correspondence: hafiz.iqbal@tec.mx (H.M.N.I.); r.parra@tec.mx (R.P.-S.)
}

Received: 21 June 2019; Accepted: 1 August 2019; Published: 7 August 2019

\begin{abstract}
Several factors have the potential to influence microalgae growth. In the present study, nitrogen concentration and light intensity were evaluated in order to obtain high biomass production and high phycoerythrin accumulation from Porphyridium purpureum. The range of nitrogen concentrations evaluated in the culture medium was $0.075-0.450 \mathrm{~g} \mathrm{~L}^{-1}$ and light intensities ranged between 30 and $100 \mu \mathrm{mol} \mathrm{m} \mathrm{m}^{-2} \mathrm{~s}^{-1}$. Surprisingly, low nitrogen concentration and high light intensity resulted in high biomass yield and phycoerythrin accumulation. Thus, the best biomass productivity $\left(0.386 \mathrm{~g} \mathrm{~L}^{-1} \mathrm{~d}^{-1}\right)$ and biomass yield (5.403 $\left.\mathrm{g} \mathrm{L}^{-1}\right)$ were achieved with $\mathrm{NaNO}_{3}$ at $0.075 \mathrm{~g} \mathrm{~L}^{-1}$ and $100 \mu \mathrm{mol} \mathrm{m} \mathrm{m}^{-2} \mathrm{~s}^{-1}$. In addition, phycoerythrin production was improved to obtain a concentration of $14.66 \mathrm{mg} \mathrm{L}^{-1}$ (2.71 $\mathrm{mg} \mathrm{g}^{-1}$ of phycoerythrin over dry weight). The results of the present study indicate that it is possible to significantly improve biomass and pigment production in Porphyridium purpureum by limiting nitrogen concentration and light intensity.
\end{abstract}

Keywords: chemical stress; physical stress; pigments; microalgae growth; phycoerythrin

\section{Introduction}

Phycoerythrin (PE) is a bioactive pigment mainly found in Rhodophyta, but it can also be recovered from Cyanobacteria [1]. This water-soluble pigment is a bioactive molecule with interesting properties such as anti-inflammatory, immunosuppressive, antitumor, antioxidant, antidiabetic, and antihypertensive effects [2-5]. In addition, PE moiety can be exploited as a fluorescent probe useful in cell tracking and imaging assays such as flow cytometry, fluorescent immunoassays, and immunophenotyping. [6,7]. As well as its application in the biotechnological and medicine areas, PE can be used in the food and cosmetic industries [8,9]. Commercial PE from microalgae has been produced by Spirulina, Rhodella, and Porphyridium [10-12]. The market price of this purified pigment is around $\$ 200 \mathrm{USD} \mathrm{mg}^{-1}$ (Sigma-Aldrich, product number: $52412-1 \mathrm{MG}-\mathrm{F}$ ), this being why $\mathrm{PE}$ is regarded as a molecule of high value [13]. Porphyridium purpureum has the ability to grow in 
different culture systems and locations [14], coupled with the capacity to produce and accumulate a large amount of $\mathrm{PE}$, which production can be enhanced when the microalgae are cultured under stress conditions [11]. The effect of different physical and nutritional factors on the culture conditions of different microalgae groups has been investigated for several purposes, including the production of biomass, pigments, oil, and other metabolites [11,15-18]. Light intensity is one of the most critical factors that influence microalgal pigment composition. This is extremely important in those microalgae who have a complex harvest light system such as Porphiridium because, for instance, PE is the major accessory light-harvesting compound in Rhodophyta $[19,20]$. On the other hand, nitrogen is a fundamental constituent for protein synthesis, cell division and it also is required for the synthesis of photosynthetic pigments [21,22]. The effect of these two factors on Porphyridium strains has been reported in some studies [23-25]. However, in most of the cases, the variables of light intensity and nitrogen concentrations have been evaluated separately. Furthermore, most of the investigations regarding light influence on the production of PE focused only in the evaluation of different wavelengths [26,27] or illumination periods [28], but scarce information is related to light intensity.

Complementing biotechnology work, mathematical models have been widely used to explore microalgae growth. The application of computational power allows us to understand, predict and optimize cellular processes present in microalgae, without the need for experimental tests [29]. Mathematical models have been used in the cultivation of P. purpureum, however, because of the complexity of these models, it is difficult to apply them [30,31]. The Gompertz model allows us to predict parameters such as maximum specific growth rate $\left(\mu_{\max }\right)$, latency phase $(\lambda)$, duplication time of microalgae cells $(G)$, productivity and because of its simplicity, it can be easily applied; however, this model has not been applied in the growth of P. purpureum [32-34].

Due to the high value and remarkable diverse bioactivities of $\mathrm{PE}$, in-depth exploration about the abiotic parameters management of microalgae cultures is needed in order to improve its production. In the present study, the effect of different light intensities and nitrogen concentrations were evaluated with the aim to obtain high biomass production and to accumulate a high PE concentration in P. purpureum. Besides the identification of the best levels of the abiotic factors evaluated, the correlation between the response variables was aimed as well.

\section{Results}

\subsection{Experimental Results and Mathematical Model Fitness}

The Gompertz model was used with the same conditions from the experimental results. In this manner, it was possible to get parameters that are not directly quantifiable. To fit this model, all the data were used in hours instead of days to have a better resolution in the model, then the time parameter was returned to days. The model was used to compare all experiments performed. The mathematical modeling to determine the biological parameters of P. purpureum culture, as well as the productivity and determination coefficient of the linear regression model obtained between the experimental and simulated results, are shown in Table 1.

The model fitness parameter used was the determination coefficient $R^{2}$, which are over $90 \%$ for almost all curves. The two experiments under $90 \%$ were in the light intensity of $65 \mu \mathrm{mol} \mathrm{m} \mathrm{m}^{-2} \mathrm{~s}^{-1}$. Both experiments had 0.075 and $0.450 \mathrm{~g} \mathrm{~L}^{-1}$ concentration of $\mathrm{NaNO}_{3}$ and were in the range of $85 \%$ which is reasonably expected to be the biological variability of growth [35].

According to the productivity of the systems that were subjected to one way ANOVA analysis and paired two-sample mean with $t$-Test analysis, the values of productivity were higher $(p=0.105)$ for $65 \mu \mathrm{mol} \mathrm{m}{ }^{-2} \mathrm{~s}^{-1}$ and significantly $(p=0.047)$ higher $100 \mu \mathrm{mol} \mathrm{m} \mathrm{m}^{-2} \mathrm{~s}^{-1}$ compared to the value registered at $30 \mu \mathrm{mol} \mathrm{m} \mathrm{m}^{-2} \mathrm{~s}^{-1}$, which were 350 and $386 \mathrm{mg} \mathrm{L}^{-1} \mathrm{~d}^{-1}$, respectively. 
Table 1. Kinetic parameters of P. purpureum cultivation under different light intensities and $\mathrm{NaNO}_{3}$ concentrations (maximum specific growth rate $\left(\mu_{\text {max }}\right)$, latency phase $(\lambda)$, duplication time of microalgae cells $(G)$, determination coefficient $\left(R^{2}\right)$ and productivity).

\begin{tabular}{|c|c|c|c|c|c|c|c|c|c|c|}
\hline & & \multicolumn{9}{|c|}{ Light Intensity $\left(\mu \mathrm{mol} \mathrm{m}{ }^{-2} \mathrm{~s}^{-1}\right)$} \\
\hline & & \multicolumn{3}{|c|}{30} & \multicolumn{3}{|c|}{65} & \multicolumn{3}{|c|}{100} \\
\hline & & \multicolumn{3}{|c|}{$\mathrm{NaNO}_{3}\left(\mathrm{~g} \mathrm{~L}^{-1}\right)$} & \multicolumn{3}{|c|}{$\mathrm{NaNO}_{3}\left(\mathrm{~g} \mathrm{~L}^{-1}\right)$} & \multicolumn{3}{|c|}{$\mathrm{NaNO}_{3}\left(\mathrm{~g} \mathrm{~L}^{-1}\right)$} \\
\hline & & 0.075 & 0.225 & 0.45 & 0.075 & 0.225 & 0.45 & 0.075 & 0.225 & 0.45 \\
\hline \multirow{3}{*}{$\begin{array}{c}\text { Gompertz } \\
\text { model constants }\end{array}$} & $\mathrm{a}$ & 0.74 & 0.88 & 2.05 & 1.33 & 1.74 & 1.04 & 1.59 & 1.03 & 2.27 \\
\hline & $\mathrm{b}$ & 9.3 & 14.26 & 1.51 & 1.76 & 1.16 & 3.11 & 1.42 & 1.28 & 1.27 \\
\hline & c & 0.07 & 0.09 & 0.007 & 0.013 & 0.006 & 0.017 & 0.009 & 0.005 & 0.008 \\
\hline$\mu_{\max }\left(\mathrm{d}^{-1}\right)$ & & 0.05 & 0.08 & 0.015 & 0.018 & 0.011 & 0.018 & 0.015 & 0.005 & 0.018 \\
\hline$\lambda(\mathrm{h})$ & & 122.3 & 139.1 & 70.64 & 56.1 & 25.72 & 124.7 & 45.13 & 56 & 34.31 \\
\hline$G(h)$ & & 13.74 & 8.22 & 46.96 & 38.23 & 62.27 & 39.37 & 46.64 & 45.78 & 39.2 \\
\hline$R^{2}(\%)$ & & 93.83 & 94.71 & 95.42 & 88.6 & 91.49 & 86.2 & 94.82 & 91.47 & 95.59 \\
\hline $\begin{array}{l}\text { Productivity } \\
\left(\mathrm{mg} \mathrm{L}^{-1} \mathrm{~d}^{-1}\right)\end{array}$ & & 173.2 & 151.8 & 138.6 & 349.8 & 208.2 & 160.6 & 386 & 258 & 259.9 \\
\hline
\end{tabular}

\subsection{Influence of Light Intensity and $\mathrm{NaNO}_{3}$ Concentration on the Production of P. purpureum Biomass}

The kinetics of the biomass production from the culture of P. purpureum under different light intensities and $\mathrm{NaNO}_{3}$ concentration is presented in Figure 1A-C. The lowest biomass production was observed at $30 \mu \mathrm{mol} \mathrm{m}^{-2} \mathrm{~s}^{-1}$ regardless of the variation of nitrogen source (Figure 1A and Table 1). Under these culture conditions $\left(30 \mu \mathrm{mol} \mathrm{m}{ }^{-2} \mathrm{~s}^{-1}\right)$, in the tests at 0.075 and $0.225 \mathrm{~g} \mathrm{~L}^{-1}$ of $\mathrm{NaNO}_{3}$, a delay in the latency phase of five days was observed, while at $0.45 \mathrm{~g} \mathrm{~L}^{-1}$ of $\mathrm{NaNO}_{3}$, it was reduced to three days (also, according to the fit parameters shown in Table 1). This could be associated with the fact that the medium had a higher concentration of this nutrient. In addition, the maximum specific growth rate and productivity values were higher for the kinetics with nitrogen source of 0.075 and $0.225 \mathrm{~g} \mathrm{~L}^{-1}$ of $\mathrm{NaNO}_{3}$ and the duplication time of microalgae cells was shorter, compared with the condition of $0.45 \mathrm{~g} \mathrm{~L}^{-1}$ of $\mathrm{NaNO}_{3}$ (see Table 1).
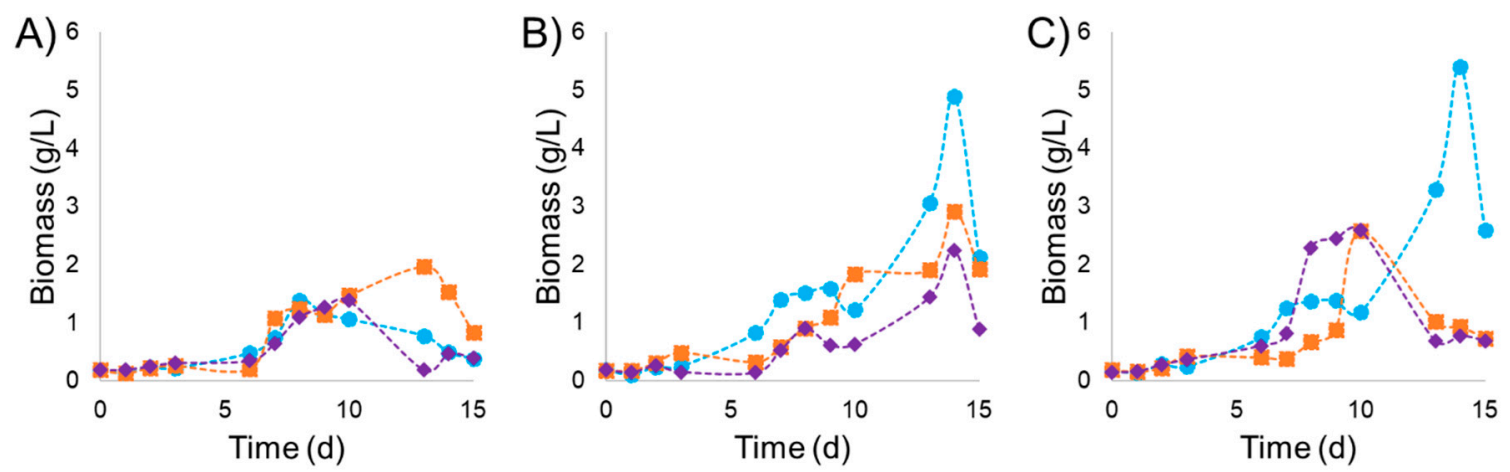

Figure 1. Biomass concentration of P. purpureum $\left(\mathrm{g} \mathrm{L}^{-1}\right)$ during cultivation under three different light intensities (A) 30, (B) 65 and (C) $100\left(\mu \mathrm{mol} \mathrm{m}{ }^{-2} \mathrm{~s}^{-1}\right)$; and three different $\mathrm{NaNO}_{3}$ concentrations 0.075 $(\bullet), 0.225(\mathbf{\square})$ and $0.450(\diamond)\left(\mathrm{g} \mathrm{L}^{-1}\right)$. The error is less than $5 \%$ or in general, so it is in the range of the symbol size.

Under a higher light intensity of $65 \mu \mathrm{mol} \mathrm{m}^{-2} \mathrm{~s}^{-1}$, a lag phase of six days and exponential phase of eight days of exponential were observed for the three concentrations of $\mathrm{NaNO}_{3}$ evaluated. Overall, the culture reached a maximum biomass concentration at day 14 , with $4.896,2.914$, and $2.248 \mathrm{~g} \mathrm{~L}^{-1}$ for $0.075,0225$, and $0.450 \mathrm{~g} \mathrm{~L}^{-1}$ of $\mathrm{NaNO}_{3}$, respectively (see Figure 1). 
Furthermore, high values of biomass were obtained under an increased light intensity at $100 \mu \mathrm{mol} \mathrm{m}^{-2} \mathrm{~s}^{-1}$ (Figure 1C). The maximum biomass production of $5.403 \mathrm{~g} \mathrm{~L}^{-1}$ was obtained at 14 days when the concentration of $\mathrm{NaNO}_{3}$ was fixed at $0.075 \mathrm{~g} \mathrm{~L}^{-1}$. The maximal production for the treatments with $\mathrm{NaNO}_{3}$ concentrations of 0.225 and $0.450 \mathrm{~g} \mathrm{~L}^{-1}$ were 2.579 and $2.598 \mathrm{~g} \mathrm{~L}^{-1}$, respectively at 10 days of culture. Culture conditions fixed at $100 \mu \mathrm{mol} \mathrm{m}^{-2} \mathrm{~s}^{-1}$ of light intensity and $0.075 \mathrm{~g} \mathrm{~L}^{-1}$ of $\mathrm{NaNO}_{3}$ concentration resulted in the highest productivity and maximum specific growth rate $\left(\mu_{\max }\right)$ with values of $0.386 \mathrm{~g} \mathrm{~L}^{-1} \mathrm{~d}^{-1}$ and $0.015 \mathrm{~d}^{-1}$, respectively. Similar productivity of $0.349 \mathrm{~g} \mathrm{~L}^{-1} \mathrm{~d}^{-1}$ was obtained under the concentration of $\mathrm{NaNO}_{3} 0.075 \mathrm{~g} \mathrm{~L}^{-1}$ by applying a light intensity of $65 \mu \mathrm{mol} \mathrm{m} \mathrm{m}^{-2} \mathrm{~s}^{-1}$. The productivity under a light intensity of $30 \mu \mathrm{mol} \mathrm{m}{ }^{-2} \mathrm{~s}^{-1}$ was lower (and independent) than that of the $\mathrm{NaNO}_{3}$ concentration. The low levels of $\mathrm{NaNO}_{3}$ resulted in a biomass of $0.950 \mathrm{~g} \mathrm{~L}^{-1}$, while the biomass obtained under the high level of $\mathrm{NaNO}_{3}$ was $0.340 \mathrm{~g} \mathrm{~L}^{-1}$. In other words, 2.79 times more biomass was obtained maintaining of $\mathrm{NaNO}_{3}$ at a low concentration.

\subsection{Influence of Light Intensity and $\mathrm{NaNO}_{3}$ Concentration on the Production of PE by P. purpureum}

The kinetics of PE production by P. purpureum under different light intensities and $\mathrm{NaNO}_{3}$ concentrations is presented in Figure 2. The experiments under a light intensity of $30 \mu \mathrm{mol} \mathrm{m} \mathrm{m}^{-2} \mathrm{~s}^{-1}$ are shown in Figure 2A. Under these culture conditions, the three experiments showed similar lag phases (6 days). A maximum PE concentration of $11.24 \mathrm{mg} \mathrm{L}^{-1}\left(5.70 \mathrm{mg} \mathrm{g}^{-1} \mathrm{PE} / \mathrm{DW}\right)$ was observed at $0.225 \mathrm{~g} \mathrm{~L}^{-1}$ of $\mathrm{NaNO}_{3}$ at the 13th day of culture. However, high PE content was detected since the ninth day $\left(10.37 \mathrm{mg} \mathrm{L}^{-1}\right)$. Similarly, $10.58 \mathrm{mg} \mathrm{L}^{-1} \mathrm{PE}$ was determined at $0.075 \mathrm{~g} \mathrm{~L}^{-1}$ of $\mathrm{NaNO}_{3}$, but obtained at the 10th day. The PE content was lower (maximum value of $4.29 \mathrm{mg} \mathrm{L}^{-1}$ ) when the concentration of $\mathrm{NaNO}_{3}$ was $0.450 \mathrm{~g} \mathrm{~L}^{-1}$. The results of $\mathrm{PE}$ concentration under a light intensity of $65 \mu \mathrm{mol} \mathrm{m}{ }^{-2} \mathrm{~s}^{-1}$ are shown in Figure 2B. Six days of a lag phase were observed when the concentration of $\mathrm{NaNO}_{3}$ was set at $0.075 \mathrm{~g} \mathrm{~L}^{-1}$. This experiment showed a long exponential phase of seven days, reaching a maximum $\mathrm{PE}$ concentration of $15.18 \mathrm{mg} \mathrm{L}^{-1}\left(3.10 \mathrm{mg} \mathrm{g}^{-1} \mathrm{PE} / \mathrm{DW}\right)$. Lower concentrations of PE (4.74 and $4.71 \mathrm{mg} \mathrm{L}^{-1}$ ) were observed when the concentration of $\mathrm{NaNO}_{3}$ was set at 0.225 and $0.450 \mathrm{~g} \mathrm{~L}^{-1}$, respectively, at day 10 . The experiments under a light intensity of $100 \mu \mathrm{mol} \mathrm{m}^{-2} \mathrm{~s}^{-1}$ are shown in Figure 2C. Maximum PE production of $14.65 \mathrm{mg} \mathrm{L}^{-1}\left(2.71 \mathrm{mg} \mathrm{g}^{-1} \mathrm{PE} / \mathrm{DW}\right)$ was obtained at day 14 , with $\mathrm{NaNO}_{3}$ at $0.075 \mathrm{~g} \mathrm{~L}^{-1}$. When the concentration of $\mathrm{NaNO}_{3}$ was $0.450 \mathrm{~g} \mathrm{~L}^{-1}$, it resulted in a maximum PE production of $10.73 \mathrm{mg} \mathrm{L}^{-1}\left(4.13 \mathrm{mg} \mathrm{g}^{-1} \mathrm{PE} / \mathrm{DW}\right)$ after 10 days. A significantly lower value of maximum PE production $\left(4.35 \mathrm{mg} \mathrm{L}^{-1}\right)$ was observed with $\mathrm{NaNO}_{3}$ concentration of $0.225 \mathrm{~g} \mathrm{~L}^{-1}$. The best value of PE productivity $\left(1.08 \mathrm{mg} \mathrm{L}^{-1} \mathrm{~d}^{-1}\right)$ was observed under a light intensity of $65 \mu \mathrm{mol} \mathrm{m}{ }^{-2} \mathrm{~s}^{-1}$ and $0.075 \mathrm{~g} \mathrm{~L}^{-1}$ of $\mathrm{NaNO}_{3}$. These same conditions were used to obtain the highest PE accumulation.
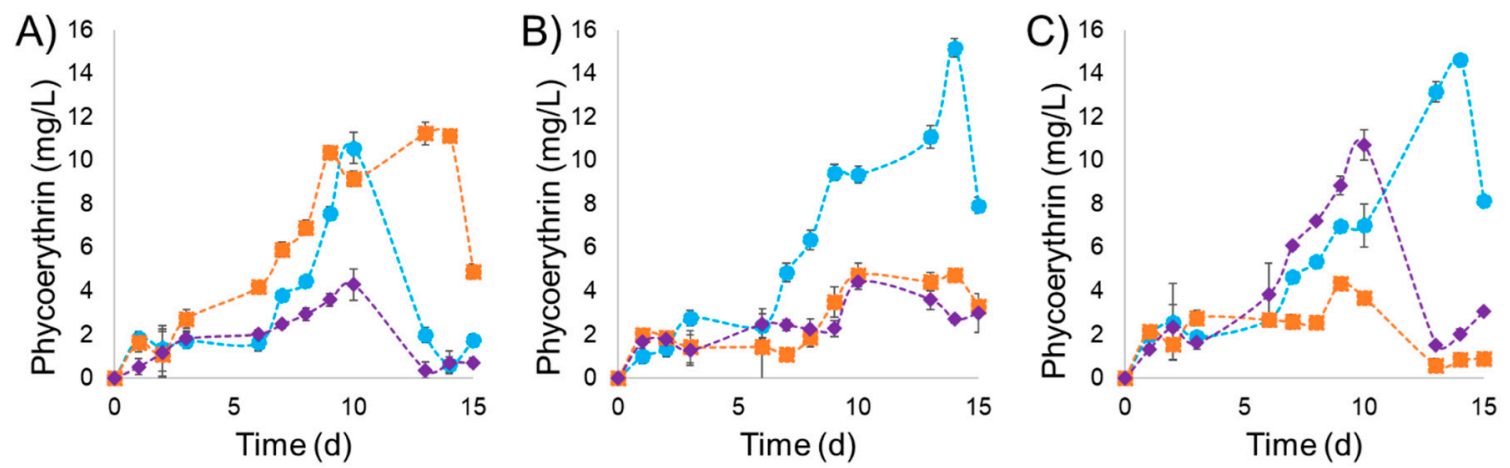

Figure 2. Phycoerythrin concentration $\left(\mathrm{mg} \mathrm{L}^{-1}\right)$ during cultivation under three different light intensities (A) 30, (B) 65 and (C) $100\left(\mu \mathrm{mol} \mathrm{m}{ }^{-2} \mathrm{~s}^{-1}\right)$; and three different $\mathrm{NaNO}_{3}$ concentrations $0.075(\bullet), 0.225(\boldsymbol{\bullet})$ and $0.450(\diamond)\left(\mathrm{g} \mathrm{L}^{-1}\right)$.

In addition, the nitrogen and phosphorus ratio was changed between the three experiments. The N:P ratio calculated for each experiment is represented by 11:1, 33:1 and 66:1 respectively with 
$0.075,0.225$ and $0.450 \mathrm{~g} \mathrm{~L}^{-1}$ concentrations of $\mathrm{NaNO}_{3}$. The best PE production is at 11:1 N:P ratio in combination with high light intensity. The higher N:P ratios did not promote PE production, except the $66: 1 \mathrm{~N}: P$ ratio at the high light intensity with a PE production of $10.73 \mathrm{mg} \mathrm{L}^{-1}\left(4.13 \mathrm{mg} \mathrm{g}^{-1} \mathrm{PE} / \mathrm{DW}\right)$ and the 33:1 ratio at the low light intensity with a PE production of $11.25 \mathrm{mg} \mathrm{L}^{-1}\left(5.70 \mathrm{mg} \mathrm{g}^{-1} \mathrm{PE} / \mathrm{DW}\right)$.

Similar to the biomass behavior, the highest values of PE content were observed under light intensities of 65 and $100 \mu \mathrm{mol} \mathrm{m}^{-2} \mathrm{~s}^{-1}$ (15.18 and $14.66 \mathrm{mg} \mathrm{L}^{-1}$, respectively) that correspond to 3.10 and $2.71 \mathrm{mg} \mathrm{g}^{-1} \mathrm{PE} / \mathrm{DW}$ when the experiments were maintained at $0.075 \mathrm{~g} \mathrm{~L}^{-1}$ of $\mathrm{NaNO}_{3}$. PE production under $65 \mu \mathrm{mol} \mathrm{m} \mathrm{m}^{-2} \mathrm{~s}^{-1}$ was reduced by $69 \%$ and $71 \%$ when the concentration of $\mathrm{NaNO}_{3}$ was increased to 0.225 and $0.450 \mathrm{mg} \mathrm{L}^{-1}$. Under the experiment at $100 \mu \mathrm{mol} \mathrm{m}^{-2} \mathrm{~s}^{-1}$, a similar effect occurred reducing PE in $70 \%$ and $27 \%$, respectively. Experiments under a light intensity of $30 \mu \mathrm{mol} \mathrm{m}^{-2} \mathrm{~s}^{-1}$ did not affect PE when the nitrate concentration increased from 0.075 to $0.225 \mathrm{~g} \mathrm{~L}^{-1}$.

The best values of PE production were observed in the experiments maintained at $0.075 \mathrm{~g} \mathrm{~L}^{-1}$. An increment of the light intensities of 65 and $100 \mu \mathrm{mol} \mathrm{m}^{-2} \mathrm{~s}^{-1}$ increased PE production by $43 \%$ and $30 \%$, respectively. However, a contrary effect was observed when the concentration of $\mathrm{NaNO}_{3}$ was fixed at $0.225 \mathrm{~g} \mathrm{~L}^{-1}$, causing a PE reduction of $57 \%$ and $61 \%$, respectively, due to the light intensities of 65 and $100 \mu \mathrm{mol} \mathrm{m} \mathrm{m}^{-2} \mathrm{~s}^{-1}$. Experiments with $\mathrm{NaNO}_{3}$ at $0.450 \mathrm{~g} \mathrm{~L}^{-1}$ did not show any effect when light intensity increased from 30 to $65 \mu \mathrm{mol} \mathrm{m} \mathrm{m}^{-2} \mathrm{~s}^{-1}$. However, when cultures were exposed to $100 \mu \mathrm{mol} \mathrm{m}{ }^{-2} \mathrm{~s}^{-1}$, PE production increased by $149 \%$.

\section{Discussion}

\subsection{Mathematical Model Parameter Analysis}

The model fitness to the experimental data was high for almost all curves (over 90\%). Even the two that were about $80 \%$ was good enough considering the biological variability of the system. The Gompertz model helped to accurately estimate the productivity and latency parameters of the P. purpureum culture. The mentioned parameters were used to distinguish the kinematics of culture growth and differentiate the actual potential to select the best conditions for biomass production.

Regarding the selection of the best set of culture conditions to maximize biomass, higher productions were found in 65 and $100 \mu \mathrm{mol} \mathrm{m}^{-2} \mathrm{~s}^{-1}$, compared to $30 \mu \mathrm{mol} \mathrm{m}{ }^{-2} \mathrm{~s}^{-1}$. For instance, the best $\mathrm{NaNO}_{3}$ concentration was $0.075 \mathrm{~g} \mathrm{~L}^{-1}$, with no significant difference $(p=0.084)$ between light intensities of 65 and $100 \mu \mathrm{mol} \mathrm{m}{ }^{-2} \mathrm{~s}^{-1}$. Although, it is possible that the higher light intensity can be better for larger volume scale with a longer light path.

\subsection{Effect of Light Intensity on Biomass and PE Production in P. purpureum}

The high impact of light intensity on biomass production by P. purpureum was evident in this study. Light intensities of 65 and $100 \mu \mathrm{mol} \mathrm{m}^{-2} \mathrm{~s}^{-1}$ resulted in increases of $253 \%$ and $390 \%$ of biomass production, respectively, compared to that obtained with $30 \mu \mathrm{mol} \mathrm{m} \mathrm{m}^{-2} \mathrm{~s}^{-1}$. However, surprisingly, this increased biomass production was observed when $\mathrm{NaNO}_{3}$ was lower than $0.075 \mathrm{~g} \mathrm{~L}^{-1}$. Experiments carried out at 0.225 and $0.450 \mathrm{~g} \mathrm{~L}^{-1}$ of $\mathrm{NaNO}_{3}$ also showed lower increments on biomass production (up to $187 \%$ ) at high light intensities. In the literature, light intensities ranging from 18.75 to $50 \mu \mathrm{mol} \mathrm{m} \mathrm{m}^{-2} \mathrm{~s}^{-1}$ resulted in biomass production in P. purpureum of up to $0.950 \mathrm{~g} \mathrm{~L}^{-1}$ [36-38]. On the other hand, higher levels of light intensity (100 to $140 \mu \mathrm{mol} \mathrm{m}^{-2} \mathrm{~s}^{-1}$ ) yielded biomass production above $2 \mathrm{~g} \mathrm{~L}^{-1}$ [26,39]. A study with Porphyridium marinum was able to produce $2 \mathrm{~g} \mathrm{~L}^{-1}$ with a light intensity of $150 \mu \mathrm{mol}$ $\mathrm{m}^{-2} \mathrm{~s}^{-1}$ to later change the condition to $70 \mu \mathrm{mol} \mathrm{m}^{-2} \mathrm{~s}^{-1}$ [40]. The trends in the present study and in the literature mentioned above indicate that high biomass production occurs at a high light intensity. A similar trend has been observed in P. purpureum SCS-2 [41] and several other microalgae strains, such as Chlorella vulgaris [42], Parachlorella sp. [19], and Spirulina platensis [43]. It is important to compare these results with other similar biomass yields found in other studies with P. purpureum (shown in Table 2). The yield of biomass production by weight is within the range of the presented reports. Our hypothesis for this effect is that low nutrient availability in the culture medium may induce 
polysaccharide, starch and/or carbohydrate accumulation, [27,44-46], and coupled with low light intensity, which promotes the accumulation of lipids $19.4 \%$ dry weight [37] and/or dark light cycle [47]. By using the mechanisms of photo-adaption and photo-protection with different light wavelengths sustained 17\% dry weight [27]. Guihéneuf and Stengel in 2015 performed a study with several culture conditions, where the nitrogen was maintained replete, limited and depleted. The results of their work show that in nitrogen depleted cultures, P. purpureum accumulates carbohydrates ( $57 \%$ dry weight), and interestingly found that the biomass productivity reached $0.15 \mathrm{~g} \mathrm{~L}^{-1} \mathrm{~d}^{-1}$.

Table 2. Comparison with recent reports of P. purpureum biomass growth and yields.

\begin{tabular}{ccccccc}
\hline $\mathbf{D W}\left(\mathbf{g ~ L}^{-\mathbf{1}}\right)$ & $\mathbf{N}\left(\mathbf{g ~ L}^{-\mathbf{1}}\right)$ & $\begin{array}{c}\text { Nitrogen } \\
\text { Source }\end{array}$ & $\mathbf{Y}(\mathbf{N} / \mathbf{D W})$ & Time (d) & $\begin{array}{c}\text { Light Intensity } \\
\left(\mu \mathbf{m o l ~ m}^{-\mathbf{2}} \mathbf{~ s}^{-\mathbf{1}}\right)\end{array}$ & Reference \\
\hline 5.54 & 1.78 & $\mathrm{KNO}_{3}$ & 0.045 & 16 & 350 & {$[41]$} \\
\hline 3.4 & 1 & $\mathrm{NaNO}_{3}$ & 0.049 & 10 & 100 & {$[23]$} \\
\hline 9.12 & 0.97 & $\mathrm{NaNO}_{3}$ & 0.018 & 14 & 18.85 & {$[24]$} \\
\hline $3.0-5.403$ & $0.075-0.45$ & $\mathrm{NaNO}_{3}$ & $0.0023-0.025$ & 14 & 100 & This report \\
\hline
\end{tabular}

Experiments under low light intensity $\left(30 \mu \mathrm{mol} \mathrm{m}{ }^{-2} \mathrm{~s}^{-1}\right)$ when the nitrate concentration increased from 0.075 to $0.225 \mathrm{~g} \mathrm{~L}^{-1}$ did not affect PE production. However, $60 \%$ of PE decrease was observed as a result of an increment of $\mathrm{NaNO}_{3}$ concentration at $0.450 \mathrm{mg} \mathrm{L}^{-1}$. A similar effect was observed by Sánchez-Saavedra since they reported a PE production of $44.45 \mu \mathrm{g} \mathrm{L}^{-1}$ under a light intensity of $200 \mu \mathrm{mol} \mathrm{m}^{-2} \mathrm{~s}^{-1}$ [25]. In contrast, the evaluation at a light intensity of $50 \mu \mathrm{mol} \mathrm{m}^{-2} \mathrm{~s}^{-1}$ caused a reduction of $60 \%$ in the PE concentration. For instance, we can hypothesize that at high light intensity more PE molecules are produced in order to harvest the maximum amount of photons reaching a limit.

It is reported in the literature that an extremely high light intensity causes low biomass yield, due to a phenomenon of photoinhibition in microalgae especially at the beginning of the curve when the culture is non-dense enough [48]. The research done by Guihéneuf and Stengel in 2015, where they explored different conditions to growth P. purpureum the best light intensity was at $100 \mu \mathrm{mol} \mathrm{m} \mathrm{m}^{-2} \mathrm{~s}^{-1}$ compared to results with 30 and $200 \mu \mathrm{mol} \mathrm{m}^{-2} \mathrm{~s}^{-1}$, where the biomass and other compounds production were decreased substantially. In accordance with Guihéneuf and Stengel, in the present study, the light intensity of $100 \mu \mathrm{mol} \mathrm{m}{ }^{-2} \mathrm{~s}^{-1}$ was the highest level evaluated and it resulted in the best biomass yield. Therefore, these results suggest that higher light levels, on the range of evaluation above of $100 \mu \mathrm{mol}$ $\mathrm{m}^{-2} \mathrm{~s}^{-1}$ could improve biomass yield as a result of the direct relationship between the increase of biomass produced and the light intensity, but at an intensity below $200 \mu \mathrm{mol} \mathrm{m} \mathrm{m}^{-2} \mathrm{~s}^{-1}$ similar to the report of Gargouch et al. (2018). This effect may be due to the evaluated strain of P. purpureum which showed high photosynthetic efficiency to transform this energy into high biomass production [49]. The photosynthetic efficiency of P. purpureum should be related to the accumulation of PE since this molecule is responsible for the light absorption [50]. Furthermore, studies on the macroalgae Gracilaria domingensis have shown this trend where high irradiance stimulated the accumulation of proteins [51].

A possibility to select a lower light intensity could arise due to the reduction of cost by using less energy for light in an upscale process. This option could be tested by the cost-benefit analysis of a larger-volume culture set-up against the possible decrease in the penetration of light through it. Moreover, other similar parameters should be tested, such as mixing, aeration, and temperature as is recommended in a previous study [27].

\subsection{Effect of Nitrogen Concentration on Biomass and Phycoerythrin from P. purpureum}

At low light intensities, the biomass production was independent of nitrate concentrations used in this study. At a high light intensity, the systems became sensitive to higher concentrations of nitrate, reducing the biomass yield. In contrast, biomass production was reduced by $50 \%$ when the concentration of $\mathrm{NaNO}_{3}$ was increased in 0.225 and $0.450 \mathrm{~g} \mathrm{~L}^{-1}$ under a light intensity of 65 and 
$100 \mu \mathrm{mol} \mathrm{m} \mathrm{m}^{-2} \mathrm{~s}^{-1}$. Therefore, the higher biomass production resulted when the lower value of $\mathrm{NaNO}_{3}$ was evaluated $\left(0.075 \mathrm{~g} \mathrm{~L}^{-1}\right)$ only when high light intensities were applied. A similar effect is reported in a study done by Kavitha et al. (2016), where they evaluated 1 and $2 \mathrm{~g} \mathrm{~L}^{-1}$ of $\mathrm{NaNO}_{3}$ for production of P. purpureum biomass. High levels of biomass (3.4-9.4 $\mathrm{g} \mathrm{L}^{-1}$ ) from P. purpureum were reported by Kathiresan et al. (2007), who suggested that low concentrations of chloride, nitrate, and phosphate did not produce any significant effect on the biomass production. However, an increment of $\mathrm{NaNO}_{3}$ above $1 \mathrm{~g} \mathrm{~L}^{-1}$ provokes a negative impact on biomass yield as well as in PE production. It is important to notice, that the main effect caused by a disproportionate increase in the concentration of nitrogen source is the possible limitation of other nutrients, such as phosphorus, trace metals and vitamins [46].

In the present study, increments of the nitrogen concentration were evaluated to obtain higher biomass production and higher PE accumulation. However, under the culture conditions evaluated, the best results were obtained at a low nitrogen concentration $\left(0.075 \mathrm{~g} \mathrm{~L}^{-1}\right)$. Phosphorous is also an important element for microalgae growth, which in conjunction with nitrogen allows biomass production; still, microalgae cannot absorb nitrogen $(\mathrm{N})$ without the presence of phosphorus $(\mathrm{P})$ in the culture, or vice versa, because a proper N:P ratio is essential for their growth [52]. The phosphorous concentration was maintained at $0.005 \mathrm{~g} \mathrm{~L}^{-1}$ (original concentration of the culture medium). The increase of nitrogen concentration changed the N:P ratio. Therefore, results suggest that nitrogen concentration could be increased, but if the N:P ratio of the original culture medium (15:1) is maintained. As studied previously by Razaghi in 2014, the results presented here show similar behavior for N:P ratio change impact the P. purpureum growth and PE production. In contrast, the report of Gargouch et al. (2018), where the strain P. marinum is used to produce PE (a maximum of $40 \mathrm{mg} / \mathrm{g}$ of PE/DW). The culture medium was optimized to produce high biomass and $\mathrm{PE}$ and the formulation contains $3.4 \mathrm{~g} \mathrm{~L}^{-1}$ of $\mathrm{NaNO}_{3}$ and $0 \mathrm{~g} \mathrm{~L}^{-1} \mathrm{~K}_{2} \mathrm{HPO}_{4}$. This reflects a complete different behavior to P. purpureum regarding the $\mathrm{N}: \mathrm{P}$ ratio in terms of this study and others $[23,24,37,41,46,52]$.

\section{Materials and Methods}

\subsection{Strain, Medium and Culture Conditions}

The marine strain Porphyridium purpureum UTEX LB 2757 was obtained from the University of Texas, United States of America. The strain was maintained in a mixture (1:1) of Bold 1NV media (UTEX, Weimar, TX, USA) and Erdshreiber media (UTEX, Weimar, TX, USA) in $500 \mathrm{~mL}$ flasks containing $300 \mathrm{~mL}$ of culture medium. The inoculum $(1: 10 \mathrm{v} / \mathrm{v})$ was cultured at $20^{\circ} \mathrm{C}$ in a flask containing $300 \mathrm{~mL}$ of culture medium mixed by bubbling sterile air at a flow rate of $25 \mathrm{~mL} \mathrm{~min}{ }^{-1}$. The culture was continuously illuminated with white fluorescent tubes with an average intensity of $65 \mu \mathrm{mol} \mathrm{m}^{-2} \mathrm{~s}^{-1}$ for 9 days. Then, aliquots of the culture were taken to seed $500 \mathrm{~mL}$ Erlenmeyer flasks filled with $270 \mathrm{~mL}$ of medium and $30 \mathrm{~mL}$ of inoculum coupled with sealed-in tubes to pass a stream of air. Two key factors, the light intensity and nitrogen limitation influencing the production of PE pigment were evaluated. The light intensity was designated as high, medium or low by adjusting different levels of the intensity $\left(100,65\right.$, and $\left.30 \mu \mathrm{mol} \mathrm{m}^{-2} \mathrm{~s}^{-1}\right)$ with a combined light with wavelengths of green and blue (520-525 and 465-468 nm). The effects of nitrogen concentration were evaluated at three levels of $\mathrm{NaNO}_{3}$ concentration $\left(0.450,0.225\right.$ and $\left.0.075 \mathrm{~g} \mathrm{~L}^{-1}\right)$, keeping the $\mathrm{F} / 2$ Phosphorous content fixed. Culture nutrient composition was based on the medium F/2 (UTEX, TX, USA), temperature and air flow rate were constant at $20^{\circ} \mathrm{C}$ and $25 \mathrm{~mL} \mathrm{~min}^{-1}$. Then, samples were collected each day within 15 days including the days 0 to 3, 6 to 10 and 13 to 14 for the analysis of total biomass and PE produced by microalgae. The microalgae biomass was washed three times with MilliQ water. The samples were centrifuged for $15 \mathrm{~min}$ at $4500 \mathrm{rpm}$. The supernatant was discarded and the pellet was resuspended in MilliQ water. Then, the sample was filtered through a Whatman regenerated cellulose membrane filter, pore size: $0.45 \mu \mathrm{m}$, diameter $4.7 \mathrm{~cm}$ followed by drying in an oven at $105^{\circ} \mathrm{C}$ for $24 \mathrm{~h}$. 


\subsection{Mathematical Model and Kinetic Parameters Calculation to Determine Growth Parameters}

In this study, the Gompertz model (Equation (1)) was used to determine maximum specific growth rate $\left(\mu_{\max }\right.$, Equation (2)), duration of the latency phase (Equation (3)), duplication time of microalgae cells (Equation (4)) and biomass productivity (Equation (5)) in experiments at different conditions of light intensity and $\mathrm{NaNO}_{3}$ concentration.

$$
Y=a e^{\left(-e^{(b-c t)}\right)}
$$

where:

$Y=\log \left(N / N_{0}\right), N_{0}$. Initial biomass $(t=0)$ in the sample $\left(\mathrm{mg} \mathrm{L}^{-1}\right)$, biomass counts for each time.

$t$ : Time (h).

$a$ : Constant determined from the experimental data. Represents the maximum population of biomass counts when time increases indefinitely.

$b$ : Constant determined from the experimental data.

$c$ : Constant determined from the experimental data.

Maximum specific growth rate:

$$
\mu_{\max }=a \times c \times(h-1)
$$

Duration of the latency phase:

$$
\lambda=(b-1) / c \times(h)
$$

Generation or duplication time:

$$
G=\ln (2) / \mu_{\max }(h)
$$

The biological parameters determined by the Gompertz model were estimated using the catalog of non-linear regression functions offered by Minitab Inc. 17.1.0 software (LEAD Technologies, Inc., Charlotte, North Carolina, USA) with the Levenberg-Marquardt algorithm.

The determination coefficient $\left(R^{2}\right)$ of linear regression model obtained between the experimental and simulated results allow us to estimate the precision of the experimental data with the model obtained, as well as the quality of the model to replicate the results. Values above $95 \%$ conclude that the model manages to replicate $95 \%$ of the experiments were carried out with very good quality.

Biomass productivity $\left(P_{x}\right)$ was calculated (Equation (5)) as follows:

$$
P_{x}=\frac{X_{\max }-X_{i}}{t_{\max }}
$$

where $X_{\max }$ and $X_{i}$ are maximum and initial biomass concentrations, respectively, and $t_{\max }$ is the time corresponding to $X_{\max }$.

\subsection{PE Extraction Methodology}

A sample of $2 \mathrm{~mL}$ from each P. purpureum culture was centrifuged at $4500 \mathrm{rpm}$ for $15 \mathrm{~min}$ and the supernatant was discarded. The sediment was mixed with $2 \mathrm{~mL}$ of distilled water and was vortexed until homogenization. The suspension was frozen at $-20{ }^{\circ} \mathrm{C}$ for one hour, and then it was thawed and sonicated in an ice bath for $10 \mathrm{~min}$. The sample was vortexed until homogenization and repeat steps until completing five cycles. After that, the samples were centrifuged at $4500 \mathrm{rpm}$ for $15 \mathrm{~min}$. The pink supernatant was recovered and measured in a spectrophotometer at 564, 592 and $455 \mathrm{~nm}$. The obtained data were substituted in the Beer and Eshel (1985) equation (Equation (6)) to calculate the concentration of PE:

$$
P E\left(m g m L^{-1}\right)=\left[\left(O D_{564 n m}-O D_{592 n m}\right)-\left(O D_{455 n m}-O D_{592 n m}\right) 0.2\right] \times 0.12
$$




\section{Conclusions}

The comparison between experimental and modeled results shows that the Gompertz model can be used correctly for modeling the Phorphyridium purpureum culture within the presented ranges of light intensities and $\mathrm{NaNO}_{3}$. This model has the potential to be a simple and powerful tool for the prediction of biomass and PE production. Although, corroboration is needed to include wider ranges of culture conditions.

Light intensity and nitrogen content resulted in strong impact factors to the biomass production of P. purpureum and its PE accumulation. The values obtained in the present study are promising since the production is within those reported in the literature, despite a low nitrogen concentration. In addition, this study is the basis for forthcoming optimization and scaling-up studies. The strategy to follow in future experiments to obtain high PE production by P. purpureum is to first promote biomass growth by using low nitrogen and high light intensity. After this nitrogen can be increased and a high light intensity can be sustained.

Author Contributions: J.E.S.-H., L.I.R.-Z., C.C.-Z., H.M.N.I. and R.P.-S. conceptualized the study; L.I.R.-Z. and C.C.-Z. perform the experiments and collected the data; J.E.S.-H., L.I.R.-Z., C.C.-Z., M.R.-A., R.d.I.C. and D.C.-N. analyzed the results; J.E.S.-H. and D.C.-N. constructed the mathematical model and evaluated parameters; J.E.S.-H., L.I.R.-Z., C.C.-Z., R.d.I.C., D.C.-N. drafted the manuscript; C.S.-S., C.F.G., C.A.L., E.J.O., R.W.L., H.M.N.I. and R.P.-S. revised the manuscript; C.F.G., R.W.L., E.J.O., H.M.N.I. and R.P.-S. coordinated the study. All authors read and approved the final manuscript.

Funding: The authors would like to thank the Sustainable Applied Biotechnology Group from Tecnologico de Monterrey, Mexico, the Institute of Ecology, Mexico and Membranology, Co, Swansea, UK. This work was totally funded by CONACYT (Mexican Council of Science and Technology) and INNOVATE UK project Phycopigments (grant number 268792).

Conflicts of Interest: The authors declare no conflict of interest.

\section{References}

1. Hirose, Y.; Misawa, N.; Yonekawa, C.; Nagao, N.; Watanabe, M.; Ikeuchi, M.; Eki, T. Characterization of the genuine type 2 chromatic acclimation in the two Geminocystis cyanobacteria. DNA Res. 2017, 24, 387-396. [CrossRef] [PubMed]

2. Sosa-Hernández, J.E.; Romero-Castillo, K.D.; Parra-Arroyo, L.; Aguilar-Aguila-Isaías, M.A.; García-Reyes, I.E.; Ahmed, I.; Parra-Saldivar, R.; Bilal, M.; Iqbal, H. Mexican Microalgae Biodiversity and State-Of-The-Art Extraction Strategies to Meet Sustainable Circular Economy Challenges: High-Value Compounds and Their Applied Perspectives. Mar. Drugs 2019, 17, 174. [CrossRef] [PubMed]

3. Lee, D.; Nishizawa, M.; Shimizu, Y.; Saeki, H. Anti-inflammatory effects of dulse (Palmaria palmata) resulting from the simultaneous water-extraction of phycobiliproteins and chlorophyll a. Food Res. Int. 2017, 100, 514-521. [CrossRef] [PubMed]

4. Li, P.; Ying, J.; Chang, Q.; Zhu, W.; Yang, G.; Xu, T.; Yi, H.; Pan, R.; Zhang, E.; Zeng, X.; et al. Effects of phycoerythrin from Gracilaria lemaneiformis in proliferation and apoptosis of SW480 cells. Oncol. Rep. 2016, 36, 3536-3544. [CrossRef] [PubMed]

5. Patel, S.N.; Sonani, R.R.; Jakharia, K.; Bhastana, B.; Patel, H.M.; Chaubey, M.G.; Singh, N.K.; Madamwar, D. Antioxidant activity and associated structural attributes of Halomicronema phycoerythrin. Int. J. Biol. Macromol. 2018, 111, 359-369. [CrossRef]

6. Al-Essa, M.K.; Melzer, S.; Tarnok, A.; Hadidi, K.A.; El-Khateeb, M. Fast RBC loading by fluorescent antibodies and nuclei staining dye and their potential bioanalytical applications. Z. Für Nat. C 2018, 73, 95-105. [CrossRef]

7. Wu, J.; Chen, H.; Zhao, J.; Jiang, P. Fusion proteins of streptavidin and allophycocyanin alpha subunit for immunofluorescence assay. Biochem. Eng. J. 2017, 125, 97-103. [CrossRef]

8. Chen, X.; Wu, M.; Yang, Q.; Wang, S. Preparation, characterization of food grade phycobiliproteins from Porphyra haitanensis and the application in liposome-meat system. LWT 2017, 77, 464-474. [CrossRef]

9. Intrarapuk, A.; Awakairt, S.; Thammapalerd, N.; Mahannop, P.; Pattanawong, U.; Suppasiri, T. Comparison between R-phycocyanin-labeled and R-phycoerythrin-labeled monoclonal antibody (Mab) probes for the detection of Entamoeba histolytica trophozoites. Southeast Asian J. Trop. Med. Public Health 2001, 32, $165-171$. 
10. Chandra, R.; Parra, R.; MN Iqbal, H. Phycobiliproteins: A novel green tool from marine origin blue-green algae and red algae. Protein Pept. Lett. 2017, 24, 118-125. [CrossRef]

11. Koch, M.; Kniggendorf, A.K.; Meinhardt-Wollweber, M.; Roth, B. In vivo determination of carotenoid resonance excitation profiles of Chlorella vulgaris, Haematococcus pluvialis, and Porphyridium purpureum. J. Raman Spectrosc. 2018, 49, 404-411. [CrossRef]

12. Rodrigues, R.D.P.; de Castro, F.C.; de Santiago-Aguiar, R.S.; Rocha, M.V.P. Ultrasound-assisted extraction of phycobiliproteins from Spirulina (Arthrospira) platensis using protic ionic liquids as solvent. Algal Res. 2018, 31, 454-462. [CrossRef]

13. Kersen, P.; Paalme, T.; Pajusalu, L.; Martin, G. Biotechnological applications of the red alga Furcellaria lumbricalis and its cultivation potential in the Baltic Sea. Bot. Mar. 2017, 60, 207-218.

14. Fuentes-Grünewald, C.; Bayliss, C.; Zanain, M.; Pooley, C.; Scolamacchia, M.; Silkina, A. Evaluation of batch and semi-continuous culture of Porphyridium purpureum in a photobioreactor in high latitudes using Fourier Transform Infrared spectroscopy for monitoring biomass composition and metabolites production. Bioresour. Technol. 2015, 189, 357-363. [CrossRef]

15. Chang, J.; Le, K.; Song, X.; Jiao, K.; Zeng, X.; Ling, X.; Shi, T.; Tang, X.; Sun, Y.; Lin, L. Scale-up cultivation enhanced arachidonic acid accumulation by red microalgae Porphyridium purpureum. Bioprocess Biosyst. Eng. 2017, 40, 1763-1773.

16. Pancha, I.; Chokshi, K.; George, B.; Ghosh, T.; Paliwal, C.; Maurya, R.; Mishra, S. Nitrogen stress triggered biochemical and morphological changes in the microalgae Scenedesmus sp. CCNM 1077. Bioresour. Technol. 2014, 156, 146-154. [CrossRef]

17. Contreras-Angulo, J.R.; Mata, T.M.; Cuellar-Bermudez, S.P.; Caetano, N.S.; Chandra, R.; Garcia-Perez, J.S.; Muylaert, K.; Parra-Saldivar, R. Symbiotic Co-Culture of Scenedesmus sp. and Azospirillum brasilense on N-Deficient Media with Biomass Production for Biofuels. Sustainability 2019, 11, 707. [CrossRef]

18. Fuentes-Grünewald, C.; Garcés, E.; Alacid, E.; Sampedro, N.; Rossi, S.; Camp, J. Improvement of lipid production in the marine strains Alexandrium minutum and Heterosigma akashiwo by utilizing abiotic parameters. J. Ind. Microbiol. Biotechnol. 2012, 39, 207-216.

19. Heo, J.; Shin, D.S.; Cho, K.; Cho, D.H.; Lee, Y.J.; Kim, H.S. Indigenous microalga Parachlorella sp. JD-076 as a potential source for lutein production: Optimization of lutein productivity via regulation of light intensity and carbon source. Algal Res. 2018, 33, 1-7. [CrossRef]

20. Sciandra, A.; Lazzara, L.; Claustre, H.; Babin, M. Responses of growth rate, pigment composition and optical properties of Cryptomonas sp. to light and nitrogen stresses. Mar. Ecol. Prog. Ser. 2000, 201, 107-120. [CrossRef]

21. Gigova, L.G.; Ivanova, N.J. Microalgae respond differently to nitrogen availability during culturing. J. Biosci. 2015, 40, 365-374. [CrossRef]

22. Singh, P.; Guldhe, A.; Kumari, S.; Rawat, I.; Bux, F. Investigation of combined effect of nitrogen, phosphorus and iron on lipid productivity of microalgae Ankistrodesmus falcatus KJ671624 using response surface methodology. Biochem. Eng. J. 2015, 94, 22-29. [CrossRef]

23. Guihéneuf, F.; Stengel, D.B. Towards the biorefinery concept: Interaction of light, temperature and nitrogen for optimizing the co-production of high-value compounds in Porphyridium purpureum. Algal Res. 2015, 10, 152-163. [CrossRef]

24. Kathiresan, S.; Sarada, R.; Bhattacharya, S.; Ravishankar, G.A. Culture media optimization for growth and phycoerythrin production from Porphyridium purpureum. Biotechnol. Bioeng. 2007, 96, 456-463. [CrossRef]

25. Del Pilar Sánchez-Saavedra, M.; Castro-Ochoa, F.Y.; Nava-Ruiz, V.M.; Ruiz-Güereca, D.A.; Villagómez-Aranda, A.L.; Siqueiros-Vargas, F.; Molina-Cárdenas, C.A. Effects of nitrogen source and irradiance on Porphyridium cruentum. J. Appl. Phycol. 2018, 30, 783-792. [CrossRef]

26. Baer, S.; Heining, M.; Schwerna, P.; Buchholz, R.; Hübner, H. Optimization of spectral light quality for growth and product formation in different microalgae using a continuous photobioreactor. Algal Res. 2016, 14, 109-115. [CrossRef]

27. Coward, T.; Fuentes-Grünewald, C.; Silkina, A.; Oatley-Radcliffe, D.L.; Llewellyn, G.; Lovitt, R.W. Utilising light-emitting diodes of specific narrow wavelengths for the optimization and co-production of multiple high-value compounds in Porphyridium purpureum. Bioresour. Technol. 2016, 221, 607-615. [CrossRef] 
28. Munier, M.; Jubeau, S.; Wijaya, A.; Morancais, M.; Dumay, J.; Marchal, L.; Jaouen, P.; Fleurence, J. Physicochemical factors affecting the stability of two pigments: R-phycoerythrin of Grateloupia turuturu and B-phycoerythrin of Porphyridium cruentum. Food Chem. 2014, 150, 400-407. [CrossRef]

29. Darvehei, P.; Bahri, P.A.; Moheimani, N.R. Model development for the growth of microalgae: A review. Renew. Sustain. Energy Rev. 2018, 97, 233-258. [CrossRef]

30. Fleck, P.; Posten, C. Modelling of growth and product formation of Porphyridium purpureum under defined conditions. IFAC Proc. Vol. 2004, 37, 281-286. [CrossRef]

31. Fleck-Schneider, P.; Lehr, F.; Posten, C. Modelling of growth and product formation of Porphyridium purpureum. J. Biotechnol. 2007, 132, 134-141. [CrossRef] [PubMed]

32. Nayak, B.K.; Das, D. Improvement of carbon dioxide biofixation in a photobioreactor using Anabaena sp. PCC 7120. Process Biochem. 2013, 48, 1126-1132. [CrossRef]

33. Zhen, G.; Lu, X.; Kobayashi, T.; Kumar, G.; Xu, K. Anaerobic co-digestion on improving methane production from mixed microalgae (Scenedesmus sp., Chlorella sp.) and food waste: Kinetic modeling and synergistic impact evaluation. Chem. Eng. J. 2016, 299, 332-341. [CrossRef]

34. Dammak, M.; Hadrich, B.; Barkallah, M.; Hentati, F.; Hlima, H.B.; Pichon, C.; Denis, M.; Fendri, I.; Michaud, P.; Abdelkafi, S. Modelling Tetraselmis sp. growth-kinetics and optimizing bioactive-compound production through environmental conditions. Bioresour. Technol. 2018, 249, 510-518. [CrossRef] [PubMed]

35. Buchanan, R.L.; Whiting, R.C.; Damert, W.C. When is simple good enough: A comparison of the Gompertz, Baranyi, and three-phase linear models for fitting bacterial growth curves. Food Microbiol. 1997, 14, 313-326. [CrossRef]

36. Assunção, M.F.; Varejão, J.M.; Santos, L.M. Nutritional characterization of the microalga Ruttnera lamellosa compared to Porphyridium purpureum. Algal Res. 2017, 26, 8-14. [CrossRef]

37. Kavitha, M.D.; Kathiresan, S.; Bhattacharya, S.; Sarada, R. Culture media optimization of Porphyridium purpureum: Production potential of biomass, total lipids, arachidonic and eicosapentaenoic acid. J. Food Sci. Technol. 2016, 53, 2270-2278. [CrossRef]

38. Schulze, C.; Wetzel, M.; Reinhardt, J.; Schmidt, M.; Felten, L.; Mundt, S. Screening of microalgae for primary metabolites including $\beta$-glucans and the influence of nitrate starvation and irradiance on $\beta$-glucan production. J. Appl. Phycol. 2016, 28, 2719-2725. [CrossRef]

39. Sandefur, H.N.; Asgharpour, M.; Mariott, J.; Gottberg, E.; Vaden, J.; Matlock, M.; Hestekin, J. Recovery of nutrients from swine wastewater using ultrafiltration: Applications for microalgae cultivation in photobioreactors. Ecol. Eng. 2016, 94, 75-81. [CrossRef]

40. Gargouch, N.; Karkouch, I.; Elleuch, J.; Elkahoui, S.; Michaud, P.; Abdelkafi, S.; Laroche, C.; Fendri, I. Enhanced B-phycoerythrin production by the red microalga Porphyridium marinum: A powerful agent in industrial applications. Int. J. Biol. Macromol. 2018, 120, 2106-2114. [CrossRef]

41. Li, T.; Xu, J.; Wu, H.; Jiang, P.; Chen, Z.; Xiang, W. Growth and Biochemical Composition of Porphyridium purpureum SCS-02 under Different Nitrogen Concentrations. Mar. Drugs 2019, 17, 124. [CrossRef] [PubMed]

42. Bazdar, E.; Roshandel, R.; Yaghmaei, S.; Mardanpour, M.M. The effect of different light intensities and light/dark regimes on the performance of photosynthetic microalgae microbial fuel cell. Bioresour. Technol. 2018, 261, 350-360. [CrossRef] [PubMed]

43. Qiang, H.; Richmond, A. Productivity and photosynthetic efficiency of Spirulina platensis as affected by light intensity, algal density and rate of mixing in a flat plate photobioreactor. J. Appl. Phycol. 1996, 8, 139-145. [CrossRef]

44. Köst, H.P.; Senser, M.; Wanner, G. Effect of nitrate and sulphate starvation on Porphyridium cruentum cells. Z. Pflanzenphysiol. 1984, 113, 231-249. [CrossRef]

45. Adda, M.; Merchuk, J.C.; Arad, S.M. Effect of nitrate on growth and production of cell-wall polysaccharide by the unicellular red alga Porphyridium. Biomass 1986, 10, 131-140. [CrossRef]

46. Razaghi, A.; Godhe, A.; Albers, E. Effects of nitrogen on growth and carbohydrate formation in Porphyridium cruentum. Open Life Sci. 2014, 9, 156-162. [CrossRef]

47. Oh, S.H.; Han, J.G.; Kim, Y.; Ha, J.H.; Kim, S.S.; Jeong, M.H.; Jeong, H.S.; Kim, N.Y.; Cho, J.S.; Yoon, W.B.; et al. Lipid production in Porphyridium cruentum grown under different culture conditions. J. Biosci. Bioeng. 2009, 108, 429-434. [CrossRef] 
48. George, B.; Pancha, I.; Desai, C.; Chokshi, K.; Paliwal, C.; Ghosh, T.; Mishra, S. Effects of different media composition, light intensity and photoperiod on morphology and physiology of freshwater microalgae Ankistrodesmus falcatus-A potential strain for bio-fuel production. Bioresour. Technol. 2014, 171, 367-374. [CrossRef]

49. Ji, F.; Hao, R.; Liu, Y.; Li, G.; Zhou, Y.; Dong, R. Isolation of a novel microalgae strain Desmodesmus sp. and optimization of environmental factors for its biomass production. Bioresour. Technol. 2013, 148, $249-254$. [CrossRef]

50. Wiltbank, L.B.; Kehoe, D.M. Two cyanobacterial photoreceptors regulate photosynthetic light harvesting by sensing teal, green, yellow, and red light. MBio 2016, 7, e02130-15. [CrossRef]

51. Ramlov, F.; Souza, J.; Faria, A.V.; Maraschin, M.; Horta, P.A.; Yokoya, N.S. Growth and accumulation of carotenoids and nitrogen compounds in Gracilaria domingensis (Kütz.) Sonder ex Dickie (Gracilariales, Rhodophyta) cultured under different irradiance and nutrient levels. Rev. Bras. Farmacogn. 2011, 21, 255-261. [CrossRef]

52. Beuckels, A.; Smolders, E.; Muylaert, K. Nitrogen availability influences phosphorus removal in microalgae-based wastewater treatment. Water Res. 2015, 77, 98-106. [CrossRef]

(C) 2019 by the authors. Licensee MDPI, Basel, Switzerland. This article is an open access article distributed under the terms and conditions of the Creative Commons Attribution (CC BY) license (http://creativecommons.org/licenses/by/4.0/). 